\title{
Bradyrhizobium and humic substances fertigation improved fertility and productivity of drip-irrigated sandy soil: Field observations on peanut (Arachis hypogaea L.)
}

\author{
Abido, W. A. E. \\ Agronomy Department, Faculty of Agriculture, Mansoura University, Mansoura, Egypt. \\ E-mail: madawy78@mans.edu.eg
}

Omar, M. M.

Soils Department, Faculty of Agriculture, Mansoura University, Mansoura, Egypt.

E-mail: elsiwy@gmail.com

Received: 20 Oct. 2019 / Accepted 05 Dec. 2019 / Publication date: 15 Jan. 2020

\begin{abstract}
Two field experiments were carried out during 2016 and 2017 summer seasons in Randomized Complete Block Design (RCBD) with five replicates under the ecological conditions of Noubaria District, Beheira Governorate, Egypt to evaluate the applicability potential of Bradyrhizobium and humic substances fertigation for improving soil fertility and productivity of peanut grown on a dripirrigated sandy soil compared to compost and mineral fertilizers applications. Physicochemical analysis revealed the high nutrients content of humic substances as well as their nano-sized diameter and abundance of active functional groups. Organic inputs (compost in particular) improved water retention and the lateral water movement in the rhizosphere compared to the prevalence of gravitydominated vertical movement in the mineral fertigation treatment. Compost application recorded the highest soil organic matter content, which decreased soil $\mathrm{pH}$ value. However, Bradyrhizobium and humic substances fertigation exhibited the highest concentrations of available nutrients $(\mathrm{N}, \mathrm{P}$ and $\mathrm{K}$ ) and nodulation parameters (nodules number and their dry weight) compared to compost and mineral fertilizers. Although mineral fertigation induced the highest vegetative growth characters, Bradyrhizobium and humic substances fertigation elicited the highest quantitative and qualitative yield indices. The current study, provides insights into the potential fertigation of $\mathrm{N}$-fixing bacteria alongside with humic substances for maximizing water and nutrient supply potentials of drip-irrigated sandy soils.
\end{abstract}

Keywords: Peanut, Humic substances, Bradyrhizobium, NPK fertilization, Drip irrigation, Sandy soils.

\section{Introduction}

Growing crops in sandy soil is vulnerable to intensive synthetic inputs. As a result, understanding the efficient strategies for improving agricultural production in these soils has recently received much attention. Ecological intensification is an innovative strategy that promote water and nutrient supply potentials of soil with the minimum use of synthetic inputs (Tilman et al., 2011). Organic farming system has been a typical framework for ecological intensification. Such system has many environmental and nutritional benefits; however, its low yield compared to conventional farming methods has been a major challenge. For instance, crop yields in organic farming system in a 21-year long study were lower than those of conventional mineral nutrition by about $20 \%$ (Mäder et al., 2002). Another long term experiment carried out in China between 1980 and 2010 suggested that mineral fertilizers could be partially replaced by organic manures to sustain the high maize yield until the soil organic carbon reaches the threshold of $\sim 42 \mathrm{MgC} \mathrm{ha}^{-1}$ (Hui et al., 2017).

The most common technique for rebuilding soil organic carbon of sandy soil depends on incorporating organic manures (compost in particular) into the plow layer (the rhizosphere) in order to maximize their water and nutrient supply potentials. However, huge amounts of these additives are applied to ensure a significant impact with extra costs of manpower. Further to this, organic manures can be a source of pathogens and weed seeds (Ingham et al., 2004). On the other hand, composting inherently contributes in increasing greenhouse gases (GHGs) emission including $\mathrm{CO}_{2}, \mathrm{CH}_{4}$ and $\mathrm{N}_{2} \mathrm{O}$

Corresponding Author: Abido, W.A.E., Agronomy Department, Faculty of Agriculture, Mansoura University, Mansoura, Egypt. E-mail: madawy78@mans.edu.eg 
(Sánchez et al., 2015). For instance, GHGs emission during composting is estimated as $789,000 \mathrm{Mg}$ of $\mathrm{CO}_{2}$ eq., representing $2.1 \%$ of the total agricultural activities contribution and $0.18 \%$ of the California's annual statewide GHGs emission (Zhu-Barker et al., 2017).

Within the context of the concept "ecological intensification", eco-friendly natural products (e.g. humic substances and biofertilizers) can provide several stimulating mechanisms for promoting plant productivity under different stress conditions. Legumes crops can be considered as typical crops for ecological intensification in sandy soils based on their low water and nutrient requirements and their significant contribution in symbiotic $\mathrm{N}_{2}$ fixation. According to Kermah et al. (2018), annual $\mathrm{N}_{2}$ fixation by legumes in poorly fertile soils can reach up to $123 \mathrm{~kg} \mathrm{~N} \mathrm{ha}^{-1}$. Peanut (Arachis hypogaea L.) is a typical leguminous crop for ecological intensification in sandy soils. However, the low retention of water and nutrients in sandy soil matrix causes a significant reduction in crop productivity due to the large amount of fruitless flowers (Zhao et al., 2015). Peanut is considering one of the most important crops success in the newly reclaimed sandy soils as a leguminous crop; contain high nutritive value and an essential source of edible oil and is the fifth important oil seed in the world come after soybean, cotton, canola and sunflower. Peanut seed contains about $25-30 \%$ digestible protein, $45-50 \%$ oil, $20 \%$ carbohydrate and $5 \%$ fiber and ash, which make a vital role to human nutrition, Ahmad and Rahim (2007). In Egypt, the total cultivated area of peanut reached about 62000 ha and the total production exceeded 199000 tonnes. However, the total cultivated area in the world reached about 27.940 million ha produce about 47.097 million tonnes, FAO (2019).

The symbiotic interactions between leguminous crops and $\mathrm{N}$-fixing bacteria (rhizobia) involved a molecular "crosstalk" between the two partners in order to invade the plant roots and trigger the formation of nodules. Plant roots release flavonoids, a group of aromatic compounds generated from the secondary metabolism of plant, into the rhizosphere as the first signal for the molecular crosstalk between leguminous crops and rhizobia. These compounds activate the bacterial transcriptional regulatory protein NodD, which is responsible for inducing the translation of other rhizobial nodulation genes (nod, nol and noe) involved in the synthesis and secretion of the main bacterial nodulation signals (Spaink 2000). Recently, it has been reported that water soluble humic substances contain flavonoid analogue, which might enhance expression of nod genes related to $\mathrm{N}_{2}$ fixation (Gao et al., 2015).

Humic substances, the final component of organic matter decomposition, can be considered as the optimum amendment for sandy soil reclamation given its recalcitrant nature that can support carbon sink in soil. Following its soil application, humic substances tend to improve water and nutrients retention in the root zone, thereby improving water and fertilizers use efficiency (Mosa 2012). The bio-stimulation of plant growth by humic substances is associated with several motivating mechanisms to the primary and secondary metabolisms involved in stress alleviation (Canellas et al., 2015). Besides, Humic substances stimulate enzymes linked to nitrogen assimilation pathways (nitrate reductase, glutamate dehydrogenase and glutamine synthetase) and thus promote nitrogen metabolism in plant (Hernandez et al., 2015, Zanin et al., 2018). Humic substances also encourage photosynthesis (particularly under stress conditions e.g. drought) via increasing the rate of gas exchange and electron transport flux in plants (Lotfi et al., 2018). In addition, humic substances stimulate secondary metabolism and thus improve the induced resistance of plant against stress conditions. For instance, humic substances showed a beneficial effect against drought stress through maintaining water absorption and cell turgor/cellular swelling (Khorasaninejad et al., 2018). Additionally, humic substances can regulate the overproduction of reactive oxygen species (ROS) generated under stress conditions through: (i) activating the antioxidative enzymatic system through interaction with the plant radicular system, and (ii) stimulating the synthesis of non-enzymatic compounds linked to shikimic pathway (phenols, alkaloids and tocopherols), which regulate ROS formation by the abundance of reversible redox sites that act as electron carriers (El-Banna et al., 2018).

The combined application of humic substances and rhizobial inoculation, therefore, can provide a cost-effective technique for ecological intensification of drip irrigated sandy soils. Various investigations have explored the effectiveness of humic substances application via drip irrigation systems (Mosa 2012, Selim and Mosa 2012, Selim et al., 2009). The novelty aspect of this study relies on applying $\mathrm{N}$-fixing bacteria via drip irrigation system either with mineral or organic fertilizers. This innovative technique can provide a long-term simultaneous localization of bioactive materials with high potentiality for ecological intensification of drip-irrigated sandy soils. The specific 
objectives of this study, therefore, are to: (1) study the integrated effect of mineral fertilizers and ecofriendly natural products (compost, humic substances and Bradyrhizobium) application on soil water retention and distribution in the rhizohsphere compared to mineral fertigation system, (2) explore the beneficial effect of experimental treatments on nutrient supply potentials of soil, and (3) evaluate the stimulating effect of experimental treatments on nodulation, growth, yield and nutrients uptake by peanut.

\section{Materials and Methods}

\section{Experimental site and layout of the experimental treatments}

Two field experiment was carried out at a private farm $\left(30^{\circ} 30 \mathrm{~N}\right.$ latitude and $30^{\circ} 20 \mathrm{E}$ longitude) located at Noubaria District, Beheira Governorate, Egypt during the growing summer seasons of 2016 and 2017. Values of meteorological data as average over both seasons are presented in Table 1. The experimental soil was sandy in texture (Entisol-Typic Torripsamments), and soil analyses were carried out according to Jackson (2005) and presented in Table 2. Irrigation water was obtained from groundwater source, and water samples were taken at each irrigation for analyzing electrical conductivity (Ec) and sodium adsorption ratio (SAR) according to Chapman and Pratt (1962). Following FAO guidelines (Ayers and Westcot 1985), water quality was acceptable for irrigation (average values of Ec and SAR were $0.66 \mathrm{dSm}^{-1}$ and 2.75, respectively).

Treatments were distributed in Randomized Complete Block Design (RCBD) with five replicates, five fertigation treatments were applied as follow: $T_{1}$ (full recommended dose of mineral NPK), $T_{2}$ (half recommended dose of mineral NPK plus humic substances), $T_{3}$ (half recommended dose of mineral NPK plus humic substances and Bradyrhizobium), $\mathrm{T}_{4}$ (half recommended dose of mineral NPK plus compost) and $\mathrm{T}_{5}$ (half recommended dose of mineral NPK plus compost and Bradyrhizobium).

Table 1: Values of meteorological data as average over both growing seasons (2016 and 2017).

\begin{tabular}{ccccc}
\hline $\begin{array}{c}\text { Meteorological } \\
\text { parameters }\end{array}$ & Air temperature $\left({ }^{\circ} \mathbf{C}\right)$ & $\begin{array}{c}\text { Relative humidity } \\
(\%)\end{array}$ & $\begin{array}{c}\text { Sunshine } \\
\text { hours (h) }\end{array}$ & $\begin{array}{c}\text { Wind speed (km } \\
\left.\text { day }^{-1}\right)\end{array}$ \\
\hline Values & 28.12 & 67.53 & 11.25 & 194.75 \\
\hline
\end{tabular}

Table 2: Some physical and chemical analyses of the experimented soil as average over both growing seasons (2016 and 2017).

\begin{tabular}{|c|c|c|c|c|c|c|c|c|}
\hline \multicolumn{3}{|c|}{ Particle size distribution (\%) } & \multirow{2}{*}{\multicolumn{2}{|c|}{$\begin{array}{l}\text { Water holding } \\
\text { capacity } \\
(\%)\end{array}$}} & \multirow{2}{*}{$\begin{array}{l}\text { hydraulic } \\
\text { conductivity } \\
\left(\mathrm{cm} \mathrm{h}^{-1}\right)\end{array}$} & \multirow{2}{*}{$\begin{array}{l}\text { Organic } \\
\text { matter } \\
(\%)\end{array}$} & \multirow{2}{*}{\multicolumn{2}{|c|}{$\begin{array}{c}\mathrm{CaCO}_{3} \\
(\%)\end{array}$}} \\
\hline Sand & Silt & Clav & & & & & & \\
\hline 80 & 11 & 9 & & 87 & 17.3 & 0.28 & & \\
\hline \multirow{2}{*}{ pH } & Ec & \multicolumn{4}{|c|}{ Available macronutrients $\left(\mathrm{mg} \mathrm{kg}^{-1}\right)$} & \multicolumn{3}{|c|}{$\begin{array}{c}\text { DTPA - extractable } \\
\text { micronutrients } \\
\left(\mathrm{mg} \mathrm{kg}^{-1}\right)\end{array}$} \\
\hline & $\left(\mathrm{dSm}^{-1}\right)$ & $\underset{\mathbf{N C l}-\text { extra }}{\mathbf{N}}$ & able & $\begin{array}{r}\text { Olsen } \\
\text { extracta }\end{array}$ & $\begin{array}{c}\text { ammonium } \\
\text { acetate - } \\
\text { extractable } K\end{array}$ & $\mathbf{F e}$ & Mn & $\mathbf{Z n}$ \\
\hline 8.2 & 0.30 & 29.1 & & 4.8 & 95.88 & 3.10 & 2.40 & 0.68 \\
\hline
\end{tabular}

\section{Materials}

Compound fertilizers (HI FRETIL, 20-10-5 NPK and 10-3-36 NPK), and humic substances (extracted from composted crop residues using 0.1 M KOH, 1:7 w/v) were purchased from Fertilizers Development Center, El-Delta Fertilizers Plant, Egypt. Peanut Bradyrhizobia strain (Bradyrhizobium japonicum USDA 3456) was obtained from Agricultural Microbiology Department, National Research Centre, Egypt. Rice straw (chopped into 2-5 cm pieces) was purchased from a private farm to serve as a feedstock for compost preparation. Seeds of peanut (Arachis hypogaea L. cv. Giza 6) were obtained from the Agricultural Research Center, Ministry of Agriculture, Egypt. 


\section{Compost preparation and analysis}

A plastic sheet was placed on soil surface to control leaching from piles during composting process. Chopped rice straw $(1000 \mathrm{~kg})$ was mixed with $20 \mathrm{~kg}$ of ammonium sulfate and $100 \mathrm{~kg}$ of farmyard manure to activate microorganisms. In piles $(3.0 \mathrm{~m}$ length, $1.0 \mathrm{~m}$ width and $0.75 \mathrm{~m}$ height), this mixture was moistened with water at $60 \%$ water holding capacity and the moisture was considered satisfactory when a hand-full of piles would wet the hand but not drip. Piles were turned for aeration once a week to enhance the aerobic decomposition process, and the composting process was allowed to continue for 105 days. Composite samples were taken from different spots of each pile to carry out the compost quality analyses according to Peters et al. (2003): total moisture content using the gravimetric method, bulk density by calculating the mass per unit volume technique, $\mathrm{pH}$ and Ec in 1:10 suspension, organic matter using back titration technique (Walkley and Black 1934), and total NPK concentrations after wet digestion using the mixture of sulfuric $\left(\mathrm{H}_{2} \mathrm{SO}_{4}\right)$ and perchloric $\left(\mathrm{HClO}_{4}\right)$ acids (nitrogen using automatic Kjeldahl equipment (Raypa DNP, 2000), phosphorus using the calorimetric determination by spectrophotometer (UV-VIS Auto UV 2602), and potassium using Jenway PFP7 flame photometer). Some physical and chemical analyses of the produced compost as average over both seasons are presented in Table 3 .

Table 3: Some physical and chemical analysis of the produced compost as average values as average over both growing seasons (2016 and 2017).

\begin{tabular}{|c|c|c|c|c|c|c|c|c|c|c|}
\hline \multirow{2}{*}{ Analysis } & \multirow{2}{*}{$\begin{array}{c}\text { Total } \\
\text { moisture } \\
(\%)\end{array}$} & \multirow{2}{*}{$\begin{array}{c}\text { Bulk } \\
\text { Density } \\
\left(\mathrm{g} \mathrm{cm}^{-3}\right)\end{array}$} & \multirow{2}{*}{ pH } & \multirow{2}{*}{$\begin{array}{c}\mathbf{E c} \\
\left(\mathrm{dSm}^{-1}\right)\end{array}$} & \multirow{2}{*}{$\begin{array}{l}\text { OM } \\
(\%)\end{array}$} & \multicolumn{3}{|c|}{$\begin{array}{c}\text { Total NPK concentrations } \\
(\%)\end{array}$} & \multirow{2}{*}{$\begin{array}{l}\mathrm{C} / \mathrm{N} \\
\text { ratio }\end{array}$} & \multirow{2}{*}{ Nematode } \\
\hline & & & & & & $\mathbf{N}$ & $\mathbf{P}$ & $\mathbf{K}$ & & \\
\hline Values & $\begin{array}{c}32.5 \\
\pm 2.49 \\
\end{array}$ & $\begin{array}{c}0.61 \\
\pm 0.06 \\
\end{array}$ & $\begin{array}{c}7.1 \\
\pm 0.43 \\
\end{array}$ & $\begin{array}{c}2.01 \\
\pm 0.12 \\
\end{array}$ & $\begin{array}{c}47.0 \\
\pm 3.50 \\
\end{array}$ & $\begin{array}{c}2.1 \\
\pm 0.12 \\
\end{array}$ & $\begin{array}{c}0.73 \\
\pm 0.06 \\
\end{array}$ & $\begin{array}{c}0.84 \\
\pm 0.05 \\
\end{array}$ & $13: 1$ & N.D. \\
\hline
\end{tabular}

Values are the mean of three measurements \pm standard deviation. N.D. means not detected.

\section{Physicochemical characterization of humic substances}

Dry matter content of liquid humic substances was determined using the gravimetric method, and contents of both humic and fulvic acids were gravimetrically determined following the certified fractionation method (Kononova 1961). $\mathrm{pH}$ value was determined using a $\mathrm{pH}$ meter (Jenway 3505 $\mathrm{pH} / \mathrm{mV} /$ Temperature Meter). Ec value was determined by HANNA (HI9835) Ec meter. Organic carbon/organic matter concentration was determined using back titration method (Walkley and Black, 1934). Cation Exchange Capacity (CEC) of humic substances was determined using the calcium acetate calcium-chloride displacement method at pH 7.0 as ascribed by Sheldrick (1984). Macro- (N, $\mathrm{P}$ and $\mathrm{K}$ ) and micronutrients ( $\mathrm{Fe}, \mathrm{Mn}$ and $\mathrm{Zn}$ ) concentration was determined after acid digestion with $\mathrm{H}_{2} \mathrm{SO}_{4}$ and $\mathrm{HClO}_{4}$ mixture (1:1): $\mathrm{N}$ using Kjeldahl method, $\mathrm{P}$ using the colorimetric method, $\mathrm{K}$ by flame photometer and micronutrients using atomic absorption spectrophotometer (Perkin Elmer model 5000).

Surface topographical analysis of humic substances was determined using scanning electron microscope (JEOL JSM-6400), and the surface elemental composition onto humic substances was characterized using energy dispersive X-ray spectroscopy (EDS, Oxford Instruments Link ISIS). The microstructure investigation of humic substances was identified using transmission electron microscopy (TEM, JEOL JEM-2100) following the dispersion of dry sample onto warm deionized water for $20 \mathrm{~min}$ and deposition onto carbon coated grid. Surface functional groups onto active surfaces of humic substances were characterized using Fourier Transform Infrared Spectroscopy (FTIR) analysis. Subsample of humic substances was mixed with $\mathrm{KBr}$ (spectroscopic grade) at rate of 100:1 (w/w) and compressed into pellets to be analyzed by a Thermo Scientific-Nicolet iS10 within the observable absorption spectra of 4000 and $400 \mathrm{~cm}^{-1}$. Some chemical analyses of humic substance as average over both seasons are presented in Table 4 . 
Table 4: Chemical analysis of humic substance as average over both growing seasons (2016 and 2017).

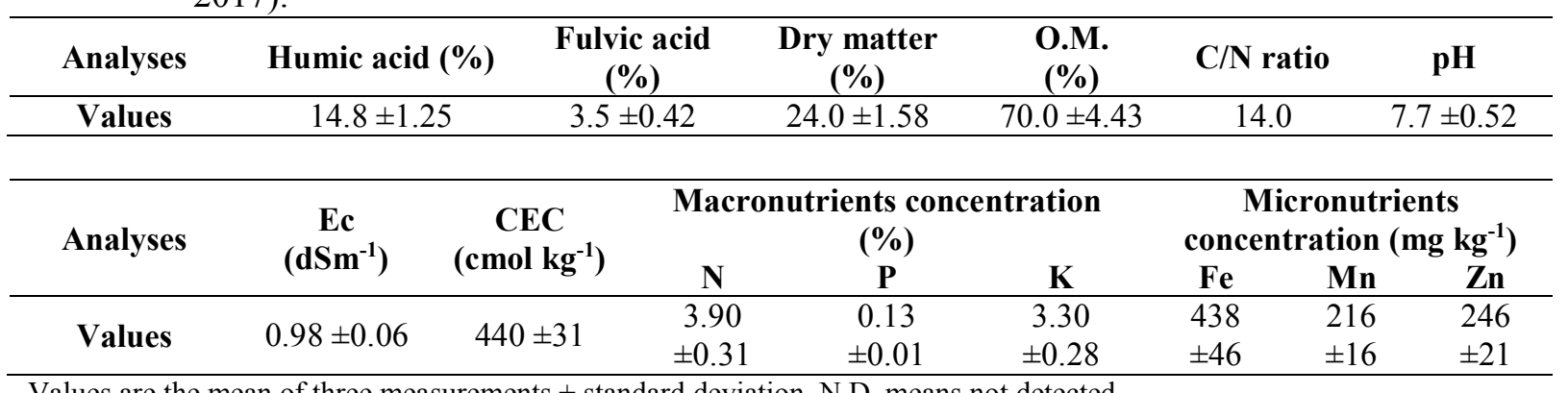

Values are the mean of three measurements \pm standard deviation. N.D. means not detected.

\section{Fertigation systems and peanut husbandry}

Soil was well prepared using a chisel plough and divided into $10.5 \mathrm{~m}^{2}$-experimental units $(3.0$ $\mathrm{m}$ breadth and $3.5 \mathrm{~m}$ length) with a $1.0 \mathrm{~m}$ border strip surrounding each plot. Compost treatments were applied before the last tillage at rate of $10 \mathrm{Mg} \mathrm{ha}^{-1}$, and the soil was left for 15 days before sowing. Under surface drip irrigation system, peanut seeds were sown by hand drilling in ridges $(0.6$ $\mathrm{m}$ spacing) at $0.1 \mathrm{~m}$ seed spacing on the $1^{\text {st }}$ of May in both seasons. Drip irrigation lines were twinwall drip tapes, and the discharge of drippers was $4 \mathrm{~L} \mathrm{~h}^{-1}$ at 1.5 bar working pressure. The recommended dose of NPK fertilization for peanut production under sandy soil conditions $(50,55$ and $72 \mathrm{~kg} \mathrm{ha}^{-1}$ for $\mathrm{N}, \mathrm{P}$ and $\mathrm{K}$, respectively) was applied from the $3^{\text {rd }}$ week until the $7^{\text {th }}$ week of fertigation program. Bradyrhizobium was cultured in a yeast extract mannitol broth medium (Vincent 1970). Cultures were incubated at $28{ }^{\circ} \mathrm{C}$ for three days on a rotary shaker until early log phase to ensure population density of $10^{9}$ colony-forming-units. In a sterilized peat moss growth media, Bradyrhizobium culture (120 ml of log phase growing culture) was injected to reach $60 \%$ of the maximum water holding capacity, mixed gently and left for a week. Cultures of bioinoculants at 500 $\mathrm{ml}\left(10^{12}\right.$ cells ml-1) was diluted to $500 \mathrm{~L} \mathrm{ha}^{-1}$ and applied through fertigation system at an interval of seven days commencing from 10 days after sowing (DAS) up to 40 DAS (four times). Humic substance was applied at $120 \mathrm{~L} \mathrm{ha}^{-1}$ at four equal doses in conjunction with the application of biofertilizer treatment. All agricultural practices for peanut plants were conducted according to the recommendation of Agricultural Research Center, Ministry of Agriculture except factors under study.

\section{Monitoring of spatial water distribution}

Composite soil samples were randomly taken from experimental plots at $0-10,10-20$, and 20 $30 \mathrm{~cm}$ distances from soil surface and 0-10, 10-20, and 20-30 cm distances from the drippers using an auger after $1 \mathrm{~h}$ from terminating irrigations to monitor spatial water distribution in the rhizosphere. Subsamples were taken by hand from composite samples following quartering technique till obtaining the appropriate weight of sample ( $\sim 5 \mathrm{~g})$ according to ISO 11464 standard. Subsamples were ovendried at $110^{\circ} \mathrm{C}$ till weight constant (about $24 \mathrm{~h}$ ) for the gravimetric determination of soil moisture content. Soil moisture content was determined fortnightly during the fertigation program. Contour maps for spatial water distributions in the rhizosphere were generated to evaluate water supply potential of soil using Surfer Software (Golden Software, Inc., Golden, CO).

\section{Peanut harvesting and chemical analysis}

After 9 weeks from sowing, five representative plant samples were picked from the outer ridges of each plot to determine foliage fresh and dry weight plant ${ }^{-1}$, numbers of total nodules plant ${ }^{-1}$ and dry weight of nodules plant ${ }^{-1}$. At maturity stage (120 DAS), all peanut plants in the three inner ridges of each plot were harvested to obtain pods yield $\left(\mathrm{Mg} \mathrm{ha}^{-1} ; \mathrm{Mg}=1000 \mathrm{~kg}\right)$ and seeds yield at $\sim 12 \%$ moisture content $\left(\mathrm{Mg} \mathrm{ha}^{-1}\right)$. Crop water productivity $\left(\mathrm{kg} \mathrm{m}^{-3}\right)$ was calculated by dividing pods yield $\left(\mathrm{kg} \mathrm{ha}^{-1}\right)$ per quantity of irrigation water applied $\left(\mathrm{m}^{3} \mathrm{ha}^{-1}\right)$. Some quality indices of seeds yield (oil and protein concentration) were determined (Association of Official Analytical 1970). Oil concentration was determined by a Soxhlet extractor using the direct gravimetric method of solvent extraction, and protein was calculated by multiplying total Kjeldahl-N by 6.25 . 
On the other hand, subsamples $(0.2 \mathrm{~g})$ of foliage and seeds were digested in $5 \mathrm{~mL}$ of a $1: 1$ $\mathrm{H}_{2} \mathrm{SO}_{4}$ and $\mathrm{HClO}_{4}$ acids mixture to determine N, P and $\mathrm{K}$ concentrations. Thereafter, NPK uptake was calculated by multiplying nutrients concentration and dry weight yield. In addition, composite soil samples were taken from each experimental plot to evaluate the effect of the experimental treatments on nutrients supply potential and some chemical properties of soil after harvesting.

\section{Statistical analysis}

All data were statistically analyzed according Duncan's multiple range test for analysis of variance (ANOVA) at confidence levels of $95 \%$ (Gomez and Gomez, 1984) by CoStat (Version 6.303, CoHort, USA, 1998-2004). Standard deviation values were obtained using Microsoft Excel Software (version 2010, Microsoft Corporation, USA). Furthermore, correlation analysis was calculated using SPSS statistical software (17.0 version; SPSS Inc., Chicago, IL) to evaluate the relationship among soil quality indices and pods yield of peanut.

\section{Results and Discussion}

\section{Physicochemical characterization of humic substances}

SEM micrographs of dry specimens showed shredded sheets in smooth granular surfaces with small pores and cavities appeared at high magnification (Fig.1a).

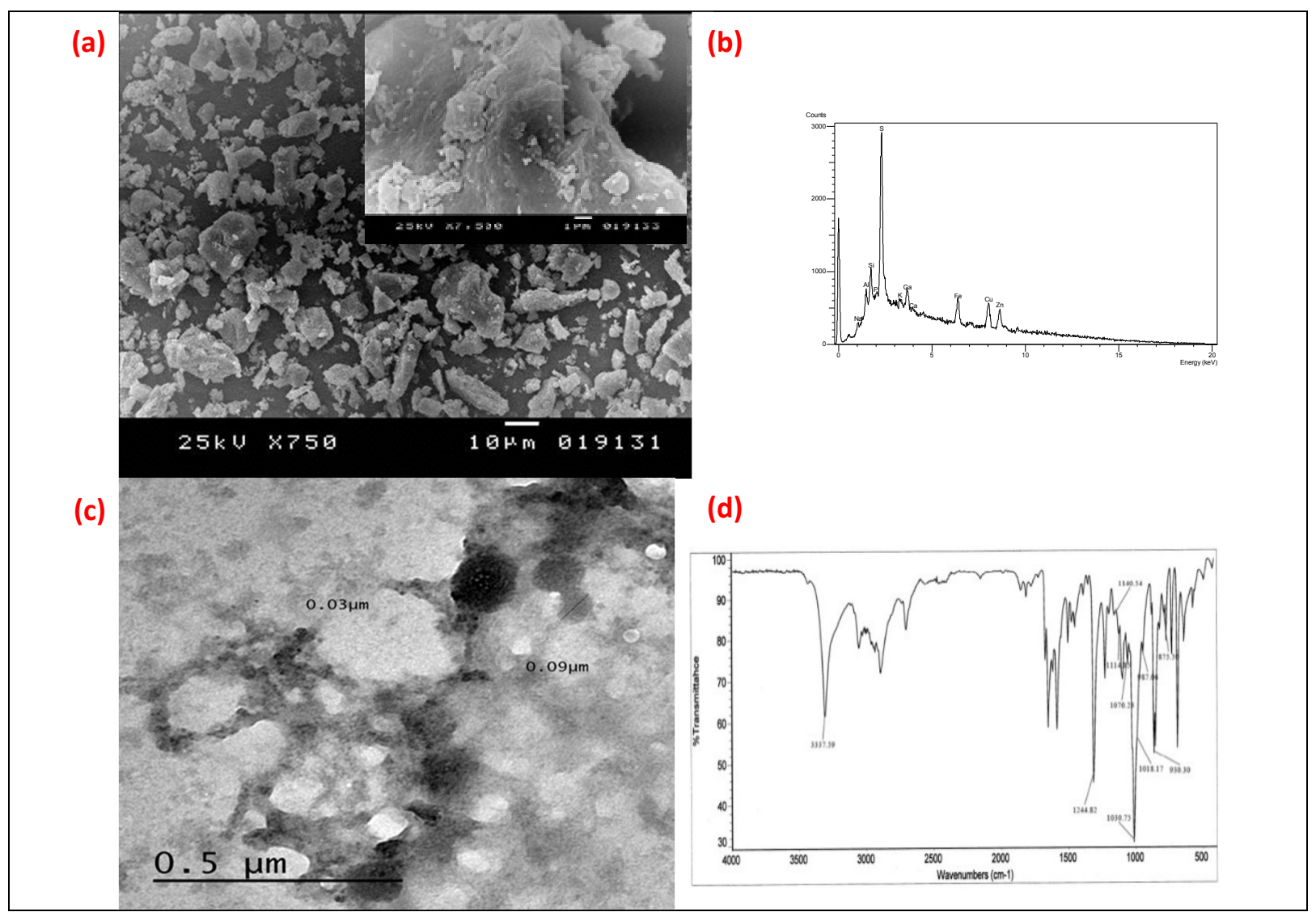

Fig. 1: Spectroscopic analyses of humic substances: (a), SEM photographs at low and high magnifications, (b) TEM micrograph of microstructure features, (c) EDS spectra mapping of elemental distribution onto humic substances surfaces, and (d) FTIR spectra of active functional groups onto humic substances surfaces.

The granular surfaces of humic substances appeared in a compacted phase with a rigid particle structure. The aggregated shape presented in SEM images reflects the cohesion forces between humic substances molecules due to involvement of charge transfer and hydrogen bonding (Das et al. 2015). These aggregates appeared in an irregular shape, which confirmed the heterogeneity of humic 
substances. TEM micrographs confirmed also the aggregated shape of humic substances particles, which appeared in a stacked-spherical shape with a nano-sized diameter (Fig.1b). The EDS spectra mapping showed high peaks of $\mathrm{Ca}, \mathrm{K}, \mathrm{Si}, \mathrm{S}, \mathrm{Al}, \mathrm{Cu}, \mathrm{Zn}, \mathrm{Mg}, \mathrm{P}$ and $\mathrm{Cl}$ (Fig.1c). The high peaks of these elements reflect the chemical constitution of the feedstock and the extraction solution (KOH).

FTIR spectra of humic substances confirmed the presence of a number of active functional groups: $-\mathrm{OH}$ stretching at $\sim 3337 \mathrm{~cm}^{-1} ; C-\mathrm{H}$ stretching at the region between 2900 and $3000 \mathrm{~cm}^{-1}$, $\mathrm{C}=\mathrm{O}$ stretching and $-\mathrm{NH}_{2}$ bending at the region between 1650 and $1750 \mathrm{~cm}^{-1}, \mathrm{C}-\mathrm{O}$ stretching at the region between 1244 and $1114 \mathrm{~cm}^{-1}, \mathrm{~S}=\mathrm{O}$ stretching at the region between 1030 and $1080 \mathrm{~cm}^{-1}$, and the high peaks located between 700 and $950 \mathrm{~cm}^{-1}$ were assigned to $\mathrm{C}-\mathrm{H}$ bending groups (Fig.1d). Functional groups characterization was identified according to the description of FTIR spectra of former investigations (El-Banna et al., 2018, Mosa et al., 2016, Song et al., 2019, Zhang et al., 2019).

\section{Soil water distribution}

Soil water content was uniformly distributed in $T_{1}$ compared to other treatments given the approximate parallel distribution of contour lines suggesting a rapid distribution of applied water across soil matrix (Fig. 2). The vertical water movement in the root zone was clearly pronounced in $\mathrm{T}_{1}$ compared to the lateral movement due to the low water retention in the root zone and the prevalence of gravity force relative to the capillary force in the root zone. In contrary, treatments received organic additives ( $T_{5}$ in particular) showed an improvement of the water retention and the lateral water movement in the root zone. In this regard, the increase of water content in the root zone of $T_{2}, T_{3}, T_{4}$ and $T_{5}$ was $32.0,35.4,37.7$ and $40.6 \%$, respectively compared to $T_{1}$. Compost application triggered the formation of soil pores (bonding space, residual, and storage pores), thereby enhanced moisture storage potentials in the rhizosphere (Głąb 2014). The pronounced effect of humic substances on improving water retention in the rhizosphere is associated with their physicochemical properties including (i) their porous nature, (ii) their nano-sized diameter and consequently their high specific surface area, and (iii) the abundance of hydrophilic functional groups on their surfaces. On the other hand, there are few reports suggested the positive effect of rhizobia inoculation on soil aggregation around the root system, which improved water retention in the rhizosphere (Alami et al., 2000).

\section{Soil chemical properties}

Data of Table 5 showed the effect of experimental treatments on soil $\mathrm{pH}$, organic matter and available concentrations of $\mathrm{N}, \mathrm{P}$ and $\mathrm{K}$ retained in soil after harvesting. Absolute mineral fertigation treatment $\left(\mathrm{T}_{1}\right)$ showed a high tendency toward raising soil $\mathrm{pH}$. Meanwhile, the $\mathrm{pH}$ value was comparable in other treatments reflecting the improvement of soil buffering capacity following organic additives application. In this regard, $\mathrm{pH}$ value was lower in treatments received compost application. Compost has an affinity to reduce soil $\mathrm{pH}$ due to generating multiple organic acids during the decomposition process (Muscolo et al., 2018). These organic acids cause an instantaneous reduction in soil $\mathrm{pH}$.

Regarding the effect of fertigation treatments on soil organic matter, it is clearly noticeable that $\mathrm{T}_{5}$ was the most efficient treatment for increasing soil organic matter without significant difference between $T_{3}$ and $T_{4}$ in both seasons. Meanwhile, $T_{1}$ recorded the lowest soil organic matter content with a reduction of about $24.1 \%$ relative to $\mathrm{T}_{5}$. As mentioned earlier, sole application of organic additives will not be able to sustain the yield intensification in such soil conditions, and supplemental mineral fertilization should be applied until the soil carbon content reaches the threshold $(\sim 42 \mathrm{Mg} \mathrm{C}$ $\left.\mathrm{ha}^{-1}\right)$. Interestingly, it is worth noting that Bradyrhizobium inoculation induced an increase in soil organic matter content taking into consideration the values of $\mathrm{T}_{4}$ and $\mathrm{T}_{5}(0.50 \mathrm{vs} .0 .52 \%$, respectively as average values over both seasons). This is mainly due to the enrichment of soil microbial community and improving plant roots architecture and nodules formation.

$\mathrm{T}_{3}$ recorded the highest $\mathrm{N}, \mathrm{P}$ and $\mathrm{K}$ concentrations in most cases. However, $\mathrm{T}_{4}$ recorded the highest $\mathrm{N}$ concentration in second season following the decomposition of soil organic matter and release of available $\mathrm{N}$ forms. Beside its key-role as a $\mathrm{N}$-fixing bacteria, there are few reports suggested the potential effect of Bradyrhizobium inoculation on solubilizing phosphate precipitates (Abd-Alla 1994). Other reports suggested its role in stimulating the activity of mycorrhiza and phosphorus solubilizing bacteria (Abd-Alla et al., 2001, Omirou et al., 2016). Beside the high concentration of available $\mathrm{N}$ in humic substances (3.9\%), the nano-sized fraction and the abundance 

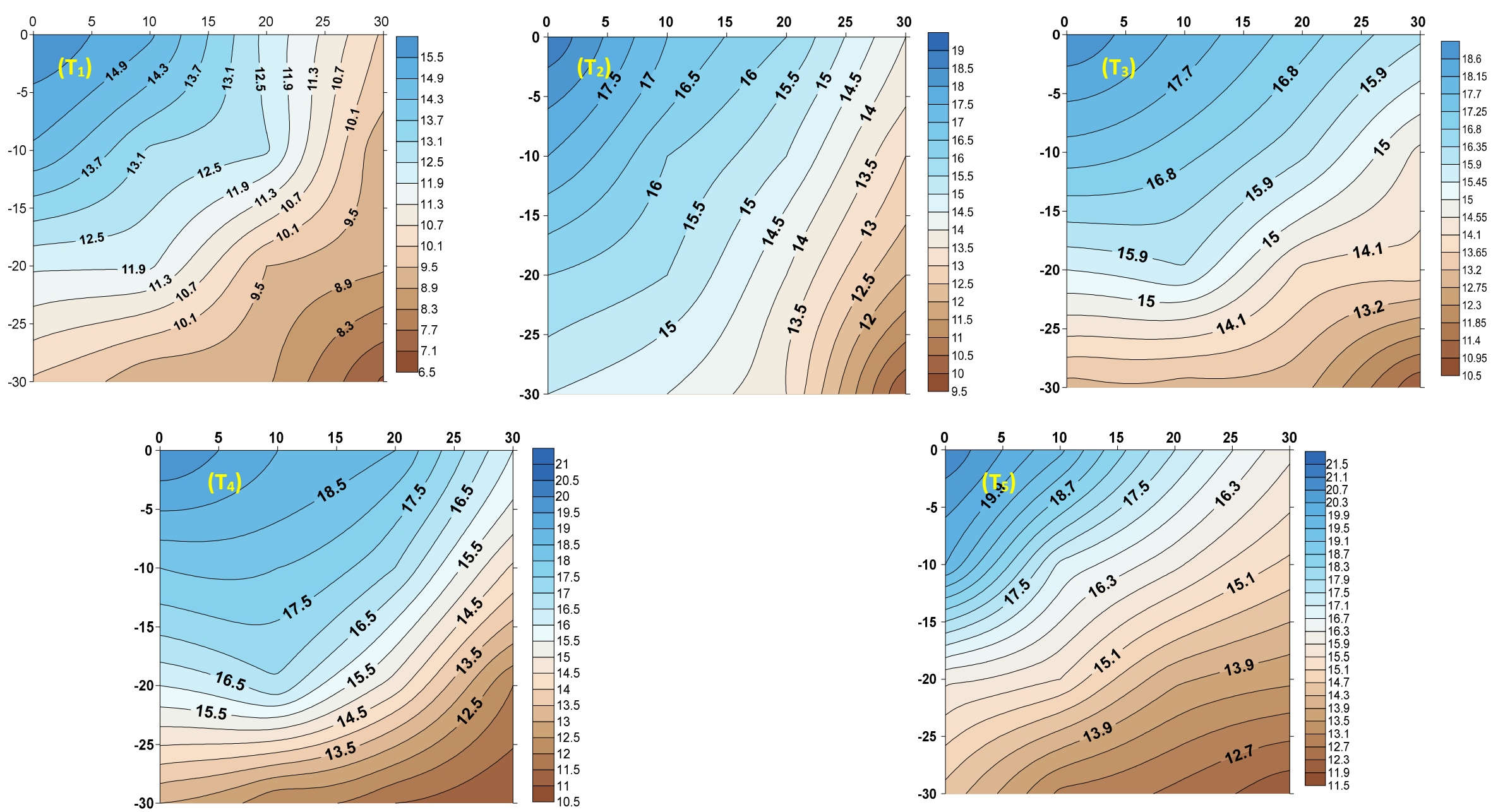

Fig. 2: Average values of spatial distribution of soil moisture content $(\%)$ in the rhizosphere $(0-30 \mathrm{~cm})$ as affected by fertigation treatments.

Data were obtained as an average values over both seasons: $\mathrm{T}_{1}$ (full recommended dose of mineral NPK), $\mathrm{T}_{2}$ (half recommended dose of mineral NPK plus humic substances), $\mathrm{T}_{3}$ (half recommended dose of mineral NPK plus humic substances and Bradyrhizobium), $\mathrm{T}_{4}$ (half recommended dose of mineral NPK plus compost) and $\mathrm{T}_{5}$ (half recommended dose of mineral NPK plus compost and Bradyrhizobium). 
of active functional groups onto surfaces of humic substances are able to bind soil available $\mathrm{N}$ against losses through leaching and/or volatilization. Humic substances fertigation showed also a significant effect toward maximizing Olsen-P recovered from soil after harvesting. There are several mechanisms responsible for enhancing $\mathrm{P}$ availability in soil: (i) the considerable amounts of extractable $\mathrm{P}$ in humic substances $(0.13 \%)$, (ii) complexation of soluble $\mathrm{Ca}^{2+}$ ions onto humic substances surfaces allowing phosphate ions to remain available against fixation as calcium phosphate, and (iii) inhibiting the precipitation of hydroxyapatite $\left(\mathrm{Ca}_{5}\left(\mathrm{PO}_{4}\right)_{3}(\mathrm{OH})\right)$ and favoring the formation of dicalcium phosphate dihydrate $\left(\mathrm{CaH}_{5} \mathrm{O}_{6} \mathrm{P}\right.$; Delgado et al., 2002). The synergistic effect of humic substances on maximizing $\mathrm{K}$ availability is also linked to their abundance of active sorption sites and reactive functional groups against $\mathrm{K}^{+}$leaching and the considerable $\mathrm{K}$ concentrations derived from organic feedstock and the extracting solution $(\mathrm{KOH})$.

\section{Above- and below-ground biomass}

Data presented in Table 6 indicated that $T_{1}$ recorded the highest fresh and dry foliage yield in both seasons. This superiority, however, was not significant relative to $T_{2}$ and $T_{3}$. There is a plenty of research suggested the effectiveness of mineral fertilizers on improving vegetative growth characters and vigour due to the rapid supply of essential plant nutrients (Emami Bistgani et al., 2018, Martínez et al., 2017, Xin et al., 2017). However, substantial alterations in the communities of soil ecosystems and the processes they control are associated with the long-term use of mineral fertilizers due to nutrients leaching and groundwater contamination, eutrophication and substantial alterations in soil acidity. A meta-analysis based on global 107 datasets from 64 long-term experimentation studies illustrated that urea and ammonia fertilizers application caused an inhibitory effect to soil microbial communities due to the temporary increase of soil $\mathrm{pH}$, osmotic potential and ammonia concentrations (Geisseler and Scow 2014).

The high fresh and dry biomass yield of $\mathrm{T}_{3}$ is associated with the integrated effect between mineral and organic fertilizers application. The partial dose of mineral fertilizers provided a fastreleased supply of plant nutrients. On the other hand, humic substances have a biostimulating effect to the pumping activities of $\mathrm{H}^{+}$-ATPase, which is responsible for ATP hydrolysis leading to excrete $\mathrm{H}^{+}$ into the apoplast (Canellas et al., 2002). The $\mathrm{H}^{+}$production generates a reduction in $\mathrm{pH}$ outside the cell and difference in the electrochemical potential across the plasma membrane, which is compensated by cations leading to stimulate plant nutrition. Furthermore, this continuous release of $\mathrm{H}^{+}$pumping stimulates the $\mathrm{pH}$-sensitive enzymes and proteins associated with the apoplast leading to cell-wall loosening and growth expansion (Hager 2003). On the other hand, Bradyrhizobia strains stimulate phytohormones production: (i) indole-3-acetic acid that accelerates cell division, vascular bundle formation, and nodules formation, (ii) cytokinins that accelerates cell division and root hairs formation, (iii) gibberellins responsible for stem elongation and leaf development, and (iv) abscisic acid, which reinforces plant defense against stress conditions (Gopalakrishnan et al., 2015).

With respect to leguminous crops, optimizing the conditions of soil microbial ecosystem is crucial to activate the nodulation process. Data of Table 6 showed that the absolute mineral fertilization led to dramatic reductions in nodules number and nodules dry weight ( 8.9 nodules and $376.1 \mathrm{mg} \mathrm{plant}^{-1}$ as an average over both seasons). This finding was supported by several reports, which confirmed the inhibitory effect of mineral fertilizers on nodulation activity (Hu et al., 2017, Saturno et al., 2017, Uddin et al., 2008). In the current study, Bradyrhizobium inoculation exhibited a vital role in encouraging nodulation process based on the superiority of inoculated treatments $\left(\mathrm{T}_{3}\right.$ and $\mathrm{T}_{5}$ ). It has been reported that indole-3-acetic acid, a phytohormone that is closely linked to genes responsible for roots nodulation and nitrogen fixation, is produced by Bradyrhizobium during the symbiosis process (Liu et al., 2017). On the other hand, nodules number and nodules dry weight showed a positive response to humic substances application. The stimulating effect of humic substances to nodulation activity was obvious in $\mathrm{T}_{3}$, which induced the superior response $(\sim 28$ nodules and $799 \mathrm{mg}$ plant $^{-1}$ as an average over both seasons). The stimulating effect of humic substances to nodulation activity was recently attributed to several mechanisms including (i) motivating cell density of CCBAU05525, (ii) bacterial activation for better bacteroid development, and (iii) enhancing expression of nod gene and $\mathrm{N}$ fixation related proteins expression in CCBAU05525 owing to the presence of flavonoid analogue, which might account for its contribution to nodD1, nodD2, nodA gene expression (Gao et al., 2015). 
Middle East J. Agric. Res., 9(1): 1-17, 2020

Table 5: Effect of different fertigation treatments on some soil chemical properties during the first and second growing seasons (2016 and 2017).

\begin{tabular}{|c|c|c|c|c|c|c|c|c|c|c|}
\hline \multirow{3}{*}{ Treatments } & \multirow{2}{*}{\multicolumn{2}{|c|}{ pH }} & \multirow{2}{*}{\multicolumn{2}{|c|}{ Organic matter $(\%)$}} & \multicolumn{6}{|c|}{ Soil available concentration of NPK $\left(\mathrm{mg} \mathrm{kg}^{-1}\right)$} \\
\hline & & & & & \multicolumn{2}{|c|}{$\mathbf{N}$} & \multicolumn{2}{|c|}{$\mathbf{P}$} & \multicolumn{2}{|c|}{$\mathbf{K}$} \\
\hline & 2016 & 2017 & 2016 & 2017 & 2016 & 2017 & 2016 & 2017 & 2016 & 2017 \\
\hline $\mathbf{T}_{1}$ & $8.53^{\mathrm{a}} \pm 0.10$ & $8.68^{\mathrm{a}} \pm 0.10$ & $0.36^{\mathrm{c}} \pm 0.025$ & $0.38^{\mathrm{b}} \pm 0.019$ & $37.75^{\mathrm{b}} \pm 0.97$ & $38.30^{\mathrm{b}} \pm 1.12$ & $9.71 \pm 0.35$ & $9.06^{\mathrm{b}} \pm 0.37$ & $110.05^{b} \pm 3.06$ & $119.96^{\mathrm{bc}} \pm 3.29$ \\
\hline $\mathbf{T}_{2}$ & $8.03^{b} \pm 0.16$ & $8.17^{\mathrm{b}} \pm 0.09$ & $0.46^{\mathrm{b}} \pm 0.018$ & $0.50^{\mathrm{a}} \pm 0.021$ & $41.07^{\mathrm{ab}} \pm 1.55$ & $40.38^{\mathrm{ab}} \pm 0.92$ & $9.41 \pm 0.28$ & $9.98^{\mathrm{ab}} \pm 0.49$ & $80.45^{\mathrm{d}} \pm 2.28$ & $100.86^{\mathrm{d}} \pm 3.66$ \\
\hline $\mathbf{T}_{3}$ & $7.99^{b} \pm 0.13$ & $7.94^{b} \pm 0.10$ & $047^{\mathrm{ab}} \pm 0.015$ & $0.51^{\mathrm{a}} \pm 0.021$ & $42.13^{\mathrm{a}} \pm 1.04$ & $38.30^{\mathrm{b}} \pm 1.18$ & $10.34 \pm 0.32$ & $11.82^{\mathrm{a}} \pm 0.22$ & $122.5^{\mathrm{a}} \pm 3.66$ & $131.7^{\mathrm{a}} \pm 4.27$ \\
\hline $\mathbf{T}_{4}$ & $7.93^{b} \pm 0.12$ & $7.99^{b} \pm 0.10$ & $0.48^{\mathrm{ab}} \pm 0.014$ & $0.52^{\mathrm{a}} \pm 0.023$ & $37.52^{\mathrm{b}} \pm 1.06$ & $42.52^{\mathrm{a}} \pm 0.82$ & $9.85 \pm 0.37$ & $10.98^{\mathrm{a}} \pm 0.53$ & $101.4^{\mathrm{c}} \pm 2.25$ & $115.20^{\mathrm{c}} \pm 3.43$ \\
\hline $\mathbf{T}_{5}$ & $7.91^{b} \pm 0.15$ & $7.92^{b} \pm 0.12$ & $0.52^{\mathrm{a}} \pm 0.013$ & $0.53^{\mathrm{a}} \pm 0.016$ & $40.51^{\mathrm{ab}} \pm 0.90$ & $41.64^{\mathrm{a}} \pm 0.70$ & $9.78 \pm 0.41$ & $10.34^{\mathrm{ab}} \pm 0.48$ & $116.1^{\mathrm{b}} \pm 3.57$ & $124.9^{\mathrm{ab}} \pm 4.25$ \\
\hline
\end{tabular}

Values are mean of five replicates \pm standard deviation. Mean values followed by the same letter are not significantly different at the $5 \%$ probability level according to LSD test. $\mathrm{T}_{1}$ (ful recommended dose of mineral NPK), $\mathrm{T}_{2}$ (half recommended dose of mineral NPK plus humic substances), $\mathrm{T}_{3}$ (half recommended dose of mineral NPK plus humic substances and Bradyrhizobium), $\mathrm{T}_{4}$ (half recommended dose of mineral NPK plus compost) and $\mathrm{T}_{5}$ (half recommended dose of mineral NPK plus compost and Bradyrhizobium).

Table 6: Effect of different fertigation treatments on above ground biomass and nodulation of peanut during the first and second growing seasons (2016 and 2017).

\begin{tabular}{|c|c|c|c|c|c|c|c|c|}
\hline \multirow{3}{*}{ Treatments } & \multicolumn{4}{|c|}{ Above-ground biomass } & \multicolumn{4}{|c|}{ Nodulation } \\
\hline & \multicolumn{2}{|c|}{$\begin{array}{c}\text { Foliage fresh weight } \\
\left(\text { g plant }^{-1}\right)\end{array}$} & \multicolumn{2}{|c|}{$\begin{array}{c}\text { Foliage dry weight } \\
\left.\text { (g plant }^{-1}\right)\end{array}$} & \multicolumn{2}{|c|}{ Nodules Number } & \multicolumn{2}{|c|}{$\begin{array}{l}\text { Nodules dry weight } \\
\left(\mathrm{mg} \mathrm{plant}^{-1}\right)\end{array}$} \\
\hline & 2016 & 2017 & 2016 & 2017 & 2016 & 2017 & 2016 & 2017 \\
\hline$T_{1}$ & $79.88^{\mathrm{a}} \pm 1.12$ & $82.89^{a} \pm 1.40$ & $21.71^{\mathrm{a}} \pm 1.31$ & $25.54^{\mathrm{a}} \pm 0.81$ & $8.0^{\mathrm{c}} \pm 0.71$ & $9.8^{\mathrm{c}} \pm 0.66$ & $311.0^{c} \pm 19.39$ & $441.2^{\mathrm{d}} \pm 10.55$ \\
\hline $\mathbf{T}_{2}$ & $77.29^{\mathrm{ab}} \pm 1.02$ & $79.07^{\mathrm{ab}} \pm 2.04$ & $20.38^{\mathrm{a}} \pm 0.93$ & $23.85^{\mathrm{ab}} \pm 1.20$ & $20.0^{\mathrm{b}} \pm 1.00$ & $23.0^{\mathrm{b}} \pm 1.05$ & $586.0^{\mathrm{b}} \pm 37.39$ & $735.36^{b} \pm 9.61$ \\
\hline $\mathbf{T}_{\mathbf{3}}$ & $78.19^{\mathrm{ab}} \pm 0.70$ & $81.63^{a} \pm 2.16$ & $21.31^{\mathrm{a}} \pm 0.87$ & $25.32^{\mathrm{a}} \pm 1.59$ & $25.2^{\mathrm{a}} \pm 1.07$ & $31.6^{\mathrm{a}} \pm 1.21$ & $721.0^{\mathrm{a}} \pm 20.27$ & $876.2^{\mathrm{a}} \pm 24.88$ \\
\hline $\mathbf{T}_{4}$ & $73.57^{\mathrm{c}} \pm 1.01$ & $76.38^{\mathrm{b}} \pm 1.85$ & $17.15^{\mathrm{ab}} \pm 0.92$ & $20.21^{\mathrm{c}} \pm 1.17$ & $19.2^{\mathrm{b}} \pm 0.71$ & $24.6^{b} \pm 1.60$ & $559.5^{\mathrm{b}} \pm 13.84$ & $666.1^{c} \pm 14.92$ \\
\hline $\mathbf{T}_{5}$ & $76.08^{b c} \pm 1.38$ & $78.13^{\mathrm{ab}} \pm 1.82$ & $18.78^{\mathrm{ab}} \pm 0.93$ & $21.78^{\mathrm{bc}} \pm 1.09$ & $21.20^{\mathrm{b}} \pm 1.32$ & $26.8^{\mathrm{b}} \pm 1.39$ & $628.5^{\mathrm{b}} \pm 24.21$ & $745.2^{b} \pm 17.89$ \\
\hline
\end{tabular}

Values are mean of five replicates \pm standard deviation. Mean values followed by the same letter are not significantly different at the $5 \%$ probability level according to LSD test. $\mathrm{T}_{1}$ (full

recommended dose of mineral NPK), $\mathrm{T}_{2}$ (half recommended dose of mineral NPK plus humic substances), $\mathrm{T}_{3}$ (half recommended dose of mineral NPK plus humic substances and Bradyrhizobium), $\mathrm{T}_{4}$ (half recommended dose of mineral NPK plus compost) and $\mathrm{T}_{5}$ (half recommended dose of mineral NPK plus compost and Bradyrhizobium). 


\section{Quantitative and qualitative yield indices}

Quantitative pods and seeds yield produced by $\mathrm{T}_{3}$ was higher than other treatments (Table 7). Compared to $T_{1}$, the increments of pods and seeds yield of $T_{3}$ reached 23.13 and $0.72 \%$, respectively as an average over both seasons. This noticeable disparity in yield increments of pods and seeds is mainly attributed to the noticeable reduction of shelling percentage in $\mathrm{T}_{3}$ compared with $\mathrm{T}_{1}(55.88 \%$ vs. $68.07 \%$ as an average over both seasons). These results are in great accordance with those obtained by Argaw (2017) who reported that combined application of Bradyrhizobium with organic and inorganic fertilizers enhanced the yield indices of peanut grown in Ethiopian sandy soil. The symbiotic performance of Bradyrhizobium strains can provide substantial amounts of available $\mathrm{N}$ to the leguminous crops. According to Hungria et al. (1998), Bradyrhizobium japonicum induced accumulation of $84 \mathrm{mg} \mathrm{N}$ plant $^{-1}$ in the rhizosphere. The ability Bradyrhizobium to provide peanut with its $\mathrm{N}$ requirements led to enhance protein concentration in the inoculated treatments (19.02 and $18.48 \%$ for $\mathrm{T}_{3}$ and $\mathrm{T}_{5}$, respectively). In addition, Bradyrhizobium inoculation showed a promoting effect on oil content in seeds, which increased fluidity of membranes and thus cells colonization by bacteria (Silva et al. 2013). Another possibility is that Bradyrhizobium inoculation promotes quantitative yield characters under drought stress condition through stimulating various metabolic and physiological plant processes. For instance, trehalose biosynthetic genes (otsA, treS, and treY) in Bradyrhizobium japonicum are induced under drought stress to provide plant with polysaccharides necessary to sustain the produced yield under such stress conditions (Khan et al., 2016).

On the other hand, the promoting effect of humic substances to yield indices of peanut is mainly attributed to the induction of carbon and nitrogen metabolism. According to Nardi et al. (2009), exogenous application of humic substances promoted the activity of enzymes involved in glucose metabolism (glucokinase, phosphoglucose isomerase, aldolase, and pyruvate kinase). Likewise, primary enzymes linked in $\mathrm{N}$ assimilation (nitrate reductase, glutamate dehydrogenase, and glutamine synthetase) are also stimulated by humic substances application (Canellas et al., 2015). The stimulating effect of humic substances on oil content in seeds may be attributed to its role in activation of secondary metabolic pathways associated with fatty acids biosynthesis. According to Noroozisharaf and Kaviani (2018), humic acid improved the expression of the phenylalanine ammonialyase, which sparks the biosynthesis of phenylpropanoid through transforming tyrosine to pcoumaric acid and phenylalanine to transcinnamic acid.

Water productivity of $\mathrm{T}_{3}$ was higher than other treatments over both seasons: $\mathrm{T}_{3}\left(1.215 \mathrm{~kg} \mathrm{~m}^{-3}\right)$ $>\mathrm{T}_{1}\left(0.995 \mathrm{~kg} \mathrm{~m}^{-3}\right)>\mathrm{T}_{2}\left(0.855 \mathrm{~kg} \mathrm{~m}^{-3}\right)>\mathrm{T}_{5}\left(0.790 \mathrm{~kg} \mathrm{~m}^{-3}\right)>\mathrm{T}_{4}\left(0.720 \mathrm{~kg} \mathrm{~m}^{-3}\right)$. This finding highlights the applicability potentials of Bradyrhizobium and humic substances fertigation to maximize water productivity in arid and semi-arid conditions.

\section{Nutrients uptake by foliage and seeds.}

$\mathrm{N}, \mathrm{P}$ and $\mathrm{K}$ uptake by foliage and seeds of plants grown in $\mathrm{T}_{1}, \mathrm{~T}_{2}$ and $\mathrm{T}_{3}$ was comparable with a slight superiority to $T_{1}$ (Table 8 ). Meanwhile, $T_{4}$ and $T_{5}$ recorded lower values relative to other treatments. Compared to $\mathrm{T}_{1}, \mathrm{~T}_{5}$ recorded reductions in $\mathrm{N}, \mathrm{P}$ and $\mathrm{K}$ uptake by about 26.19, 28.37 and $31.31 \%$, respectively as an average over both seasons. This finding highlights the importance of humic substances to sustain nutrients requirements of drip-irrigated peanut alongside with the partial dose of mineral fertigation. Humic substances induce the activity of $\mathrm{H}^{+}$-ATPase, and thus stimulate secondary ion transporters and consequently N, P and K uptake (Canellas et al., 2015). For example, the generation of $\mathrm{H}^{+}$electrical gradient across the plasma membrane following ATP hydrolysis can provide a motive force for $\mathrm{K}$ uptake by plant. Other reports highlighted the promotion of nitrate uptake (the dominant form of soil available $\mathrm{N}$ ) due to the stimulating effect of humic substances to BnNRT1.1 and BnNRT2.1; genes encoding nitrate transporters (Jannin et al., 2012). A recent study suggested also the stimulating effect of phosphorus uptake due to the key role of phenols and lignin derivatives from humic substances (Spaccini et al., 2019).

Beside the crucial effect of Bradyrhizobium inoculation on providing peanut with its $\mathrm{N}$ requirements, it seems that it has a stimulating effect on $\mathrm{P}$ and $\mathrm{K}$ uptake, especially when applied alongside with humic substances. Phytate (the dominant form of identifiable organic phosphorus) is unavailable for uptake by plants. However, this unavailable form can be hydrolyzed by phytase enzyme into readily available form. The abundance of phytase in nodules, and its contribution to the survival of rhizobia-legume symbiosis under deficient-phosphorus soils has been reported (Lazali et 
Table 7: Effect of different fertigation treatments on pod and seed yields $/ \mathrm{ha}$, shelling $\%$, protein $\%$, oil $\%$ and crop water productivity $/ \mathrm{m}^{-3}$ of peanut during the first and second growing seasons (2016 and 2017).

\begin{tabular}{|c|c|c|c|c|c|c|c|c|c|c|c|c|}
\hline \multirow{3}{*}{ Treatments } & \multicolumn{4}{|c|}{ Yield $\left(\mathrm{Mg} \mathrm{ha}^{-1}\right)$} & \multirow{2}{*}{\multicolumn{2}{|c|}{$\begin{array}{c}\text { Shelling } \\
(\%)\end{array}$}} & \multirow{2}{*}{\multicolumn{2}{|c|}{$\begin{array}{c}\text { Protein } \\
(\%)\end{array}$}} & \multirow{2}{*}{\multicolumn{2}{|c|}{$\begin{array}{l}\text { Oil } \\
(\%)\end{array}$}} & \multirow{2}{*}{\multicolumn{2}{|c|}{$\begin{array}{c}\text { Crop water } \\
\text { productivity } \\
\left(\mathrm{kg} \mathrm{m}^{-3}\right)\end{array}$}} \\
\hline & \multicolumn{2}{|c|}{ Pod } & \multicolumn{2}{|c|}{ Seed } & & & & & & & & \\
\hline & 2016 & 2017 & 2016 & 2017 & 2016 & 2017 & 2016 & 2017 & 2016 & 2017 & 2016 & 2017 \\
\hline & $3.69^{\mathrm{b}}$ & $4.48^{\mathrm{b}}$ & $2.57^{\mathrm{a}}$ & $2.97^{\mathrm{a}}$ & $69.57^{\mathrm{a}}$ & $66.56^{\mathrm{ab}}$ & $18.30^{\mathrm{ab}}$ & $19.02^{\mathrm{ab}}$ & $49.54^{\mathrm{c}}$ & $49.90^{\mathrm{d}}$ & & \\
\hline $\mathbf{T}_{1}$ & \pm 0.14 & \pm 0.15 & \pm 0.22 & \pm 0.08 & \pm 1.61 & \pm 1.66 & \pm 0.30 & \pm 0.47 & \pm 0.62 & \pm 0.48 & 0.90 & 1.09 \\
\hline & $3.31^{\mathrm{bc}}$ & $3.74^{\mathrm{c}}$ & $2.27^{\mathrm{ab}}$ & $2.62^{\mathrm{b}}$ & $68.84^{\mathrm{ab}}$ & $70.10^{\mathrm{a}}$ & $18.84^{\mathrm{a}}$ & $19.4^{\mathrm{ab}}$ & $51.39^{\mathrm{b}}$ & $52.00^{c}$ & & \\
\hline$T_{2}$ & \pm 0.15 & \pm 0.12 & \pm 0.16 & \pm 0.07 & \pm 1.56 & \pm 1.24 & \pm 0.14 & \pm 0.46 & \pm 0.48 & \pm 0.45 & 0.80 & 0.91 \\
\hline & $4.84^{\mathrm{a}}$ & $5.22^{\mathrm{a}}$ & $2.60^{\mathrm{a}}$ & $2.98^{\mathrm{a}}$ & $53.74^{\mathrm{c}}$ & $58.01^{\mathrm{c}}$ & $19.02^{\mathrm{a}}$ & $20.36^{\mathrm{a}}$ & $53.72^{\mathrm{a}}$ & $53.16^{\mathrm{b}}$ & 118 & \\
\hline $\mathbf{T}_{3}$ & \pm 0.29 & \pm 0.14 & \pm 0.15 & \pm 0.08 & \pm 1.62 & \pm 1.49 & \pm 0.20 & \pm 0.44 & \pm 0.42 & \pm 0.33 & 1.18 & 1.25 \\
\hline & $2.81^{\mathrm{c}}$ & $3.11^{\mathrm{d}}$ & $1.80^{\mathrm{c}}$ & $2.17^{\mathrm{c}}$ & $66.93^{\mathrm{ab}}$ & $70.47^{\mathrm{a}}$ & $17.97^{\mathrm{b}}$ & $18.32^{\mathrm{b}}$ & $54.47^{\mathrm{a}}$ & $54.24^{\mathrm{a}}$ & & \\
\hline $\mathbf{T}_{4}$ & \pm 0.13 & \pm 0.10 & \pm 0.15 & \pm 0.11 & \pm 1.34 & \pm 1.18 & \pm 0.31 & \pm 0.49 & \pm 0.30 & \pm 0.41 & 0.68 & 0.76 \\
\hline $\mathbf{T}_{\tilde{\sigma}}$ & $3.08^{b c}$ & $3.40^{\mathrm{cd}}$ & $1.92^{\mathrm{bc}}$ & $2.19^{c}$ & $64.04^{\mathrm{b}}$ & $64.50^{\mathrm{b}}$ & $18.48^{\mathrm{ab}}$ & $19.02^{\mathrm{ab}}$ & $53.34^{\mathrm{a}}$ & $53.00^{\mathrm{b}}$ & & \\
\hline$T_{5}$ & \pm 0.24 & \pm 0.14 & \pm 0.11 & \pm 0.11 & \pm 2.06 & \pm 1.42 & \pm 0.21 & \pm 0.47 & \pm 0.49 & \pm 0.36 & 0.75 & 0.83 \\
\hline
\end{tabular}

Values are mean of five replicates \pm standard deviation. Mean values followed by the same letter are not significantly different at the $5 \%$ probability level according to LSD test. T 1 (full recommended dose of mineral NPK), $T_{2}$ (half recommended dose of mineral NPK plus humic substances), $T_{3}$ (half recommended dose of mineral NPK plus humic substances and Bradyrhizobium), $\mathrm{T}_{4}$ (half recommended dose of mineral NPK plus compost) and $\mathrm{T}_{5}$ (half recommended dose of mineral NPK plus compost and Bradyrhizobium).

Table 8: Effect of different fertigation treatments on nutrients concentration uptake in foliage and seeds of peanut during the first and second growing seasons (2016 and 2017).

\begin{tabular}{|c|c|c|c|c|c|c|c|c|c|c|c|c|}
\hline \multirow{3}{*}{ Treatments } & \multicolumn{6}{|c|}{ Nutrients uptake by foliage $\left(\mathrm{kg} \mathrm{ha}^{-1}\right)$} & \multicolumn{6}{|c|}{ Nutrients uptake by seeds $\left(\mathrm{kg} \mathrm{ha}^{-1}\right)$} \\
\hline & \multicolumn{2}{|c|}{$\mathbf{N}$} & \multicolumn{2}{|c|}{$\mathbf{P}$} & \multicolumn{2}{|c|}{$\mathbf{K}$} & \multicolumn{2}{|c|}{$\mathbf{N}$} & \multicolumn{2}{|c|}{$\mathbf{P}$} & \multicolumn{2}{|c|}{$\mathbf{K}$} \\
\hline & 2016 & 2017 & 2016 & 2017 & 2016 & 2017 & 2016 & 2017 & 2016 & 2017 & 2016 & 2017 \\
\hline \multirow[b]{2}{*}{$\mathbf{T}_{1}$} & $170.24^{\mathrm{a}}$ & $184.68^{\mathrm{a}}$ & $69.08^{\mathrm{a}}$ & $75.46^{\mathrm{a}}$ & $121.03^{\mathrm{a}}$ & $146.83^{\mathrm{a}}$ & $78.30^{\mathrm{a}}$ & $84.64^{\mathrm{a}}$ & $8.50^{\mathrm{a}}$ & $8.94^{\mathrm{a}}$ & $58.42^{\mathrm{a}}$ & $71.92^{\mathrm{a}}$ \\
\hline & \pm 4.61 & \pm 4.32 & \pm 2.72 & \pm 1.94 & \pm 2.28 & \pm 4.00 & \pm 2.94 & \pm 2.59 & \pm 0.43 & \pm 0.23 & \pm 2.27 & \pm 1.96 \\
\hline \multirow{2}{*}{$\mathbf{T}_{\mathbf{2}}$} & $167.87^{\mathrm{a}}$ & $183.96^{\mathrm{a}}$ & $63.05^{\mathrm{a}}$ & $69.44^{\mathrm{a}}$ & $112.2^{\mathrm{a}}$ & $140.11^{\mathrm{a}}$ & $68.29^{\mathrm{b}}$ & $72.82^{\mathrm{b}}$ & $7.78^{\mathrm{a}}$ & $8.78^{\mathrm{a}}$ & $49.82^{\mathrm{b}}$ & $68.02^{\mathrm{a}}$ \\
\hline & \pm 5.45 & \pm 4.83 & \pm 2.33 & \pm 2.52 & \pm 3.48 & \pm 2.75 & \pm 1.43 & \pm 3.03 & \pm 0.26 & \pm 0.29 & \pm 1.83 & \pm 2.08 \\
\hline \multirow[b]{2}{*}{$\mathbf{T}_{3}$} & $163.94^{\mathrm{a}}$ & $176.50^{\mathrm{a}}$ & $64.89^{\mathrm{a}}$ & $70.02^{\mathrm{a}}$ & $118.03^{\mathrm{a}}$ & $145.62^{\mathrm{a}}$ & $76.90^{\mathrm{a}}$ & $84.04^{\mathrm{a}}$ & $8.05^{\mathrm{a}}$ & $8.68^{a}$ & $60.22^{\mathrm{a}}$ & $68.90^{\mathrm{a}}$ \\
\hline & \pm 5.06 & \pm 4.21 & \pm 1.98 & \pm 1.78 & \pm 4.45 & \pm 3.97 & \pm 2.59 & \pm 2.54 & \pm 0.30 & \pm 0.26 & \pm 1.65 & \pm 2.23 \\
\hline \multirow{2}{*}{$\mathbf{T}_{4}$} & $148.16^{b}$ & $158.50^{b}$ & $53.23^{\mathrm{b}}$ & $60.22^{\mathrm{b}}$ & $98.27^{b}$ & $115.27^{b}$ & $54.14^{\mathrm{c}}$ & $66.40^{\mathrm{b}}$ & $5.48^{\mathrm{b}}$ & $6.48^{\mathrm{b}}$ & $37.98^{c}$ & $44.47^{b}$ \\
\hline & \pm 4.30 & \pm 4.31 & \pm 2.92 & \pm 2.32 & \pm 3.96 & \pm 3.87 & \pm 1.63 & \pm 2.38 & \pm 0.28 & \pm 0.16 & \pm 1.76 & \pm 2.11 \\
\hline \multirow{2}{*}{$\mathbf{T}_{5}$} & $129.15^{\mathrm{c}}$ & $132.82^{c}$ & $44.08^{c}$ & $59.46^{\mathrm{b}}$ & $85.25^{c}$ & $98.75^{\mathrm{c}}$ & $56.34^{\mathrm{c}}$ & $66.88^{\mathrm{b}}$ & $5.74^{\mathrm{b}}$ & $6.40^{\mathrm{b}}$ & $45.88^{\mathrm{b}}$ & $41.38^{\mathrm{b}}$ \\
\hline & \pm 5.89 & \pm 4.06 & \pm 1.99 & \pm 1.68 & \pm 2.29 & \pm 4.71 & \pm 1.42 & \pm 2.34 & \pm 0.31 & \pm 0.21 & \pm 2.49 & \pm 2.46 \\
\hline
\end{tabular}

Values are mean of five replicates \pm standard deviation. Mean values followed by the same letter are not significantly different at the $5 \%$ probability level according to LSD test. $\mathrm{T}_{1}$ (full recommended dose of mineral NPK), $\mathrm{T}_{2}$ (half recommended dose of mineral NPK plus humic substances), $\mathrm{T}_{3}$ (half recommended dose of mineral NPK plus humic substances and Bradyrhizobium), $\mathrm{T}_{4}$ (half recommended dose of mineral NPK plus compost) and $\mathrm{T}_{5}$ (half recommended dose of mineral NPK plus compost and Bradyrhizobium). 
al., 2013). The beneficial effect of Bradyrhizobium inoculation was also obvious with potassium in the current study. Such stimulating effect may be associated with the presence of K-uptake related genes in Bradyrhizobium genome. According to Domínguez-Ferreras et al. (2009), the in silico investigations confirmed the presence of genes responsible for potassium uptake (1021: Kup1, Kup2, Trk, and Kdp) in the genome of Sinorhizobium meliloti (a nitrogen fixing bacteria).

\section{Correlation matrix for soil quality indices and peanut pods yield}

A Pearson's correlation analysis was performed to analyze the relationships among average values of soil quality indices and peanut pods yield over both seasons (Table 9). It seems that pods yield $\left(\mathrm{Mg} \mathrm{ha}^{-1}\right)$ showed significant correlation $(P<0.01)$ with soil available $\mathrm{K}(r=0.510)$ suggesting that this variable is the main limiting factor for pods yield formation. Potassium plays several metabolic functions for peanut production grown in such soil conditions including adjusting water status of plant, regulating stomata functionality, activating photosynthesis and protein synthesis pathways, stimulating $\mathrm{N}$ fixation and translocation of photosynthates from leaves into nodules (Almeida et al., 2015). Surprisingly, it is clear that peanut pods yield showed a negative correlation with soil organic matter concentration $(r=-0.311)$ suggesting that quality of soil organic matter (humification rate, the presence of active functional groups, aromacity, the nano-sized fraction and nutrients content) is more crucial than its quantity. Soil moisture content showed a high correlation with both of soil organic matter $(r=0.528)$ and soil $\mathrm{pH}(r=-0.635)$ suggesting the crucial effect of soil moisture content on regulating the decomposition rate of organic matter, thus reducing the generation of organic acids and $\mathrm{CO}_{2}$. Soil available $\mathrm{N}$ showed also a high significant correlation with soil available $\mathrm{P}(\mathrm{r}=0.550, P<0.01)$. This finding confirmed the importance of soil available $\mathrm{P}$ to the symbiotic fixation of $\mathrm{N}$ by Bradyrhizobium. Soil available $\mathrm{N}$ showed also a significant correlation $(P$ $<0.05)$ with available $\mathrm{K}(r=-0.497)$ and soil $\mathrm{pH}(r=-0.411)$. Soil available $\mathrm{P}$ showed a negative significant correlation with soil $\mathrm{pH}(\mathrm{r}=-0.511, P<0.01)$ confirming the vital role of soil $\mathrm{pH}$ reduction on phosphate solubilization. Soil organic matter showed a high significant correlation with soil $\mathrm{pH}(\mathrm{r}=-0.806, P<0.01)$ confirming the aforementioned reduction of soil $\mathrm{pH}$ following organic matter decomposition.

Table 9: Correlation matrix for average values of soil quality indices and peanut pods yield as average over both growing seasons.

\begin{tabular}{|c|c|c|c|c|c|c|c|}
\hline & $\begin{array}{r}\text { Pods yield } \\
\left(\mathrm{Mg} \mathrm{ha}^{-1}\right)\end{array}$ & $\begin{array}{c}\text { Soil moisture } \\
\text { content } \\
(\%) \\
\end{array}$ & $\begin{array}{c}\text { Soil available } \\
\mathrm{N} \\
\left(\mathrm{mg} \mathrm{kg}^{-1}\right) \\
\end{array}$ & $\begin{array}{c}\text { Soil available } \\
\mathbf{P} \\
\left(\mathrm{mg} \mathrm{kg} \mathbf{~ k g}^{-1}\right) \\
\end{array}$ & $\begin{array}{c}\text { Soil available } \\
\mathrm{K} \\
(\mathrm{mg} \mathrm{kg-1})\end{array}$ & $\begin{array}{l}\text { Soil } \\
\text { OM } \\
(\%) \\
\end{array}$ & $\begin{array}{l}\text { Soil } \\
\text { pH }\end{array}$ \\
\hline Pods yield (Mg ha $\left.{ }^{-1}\right)$ & 1 & & & & & & \\
\hline Soil moisture content (\%) & 0.118 & 1 & & & & & \\
\hline Soil available $N\left(\mathrm{mg} \mathrm{kg}^{-1}\right)$ & 0.374 & 0.248 & 1 & & & & \\
\hline Soil available $P\left(\mathrm{mg} \mathrm{kg}^{-1}\right)$ & 0.251 & 0.382 & $0.550^{* *}$ & 1 & & & \\
\hline Soil available $K\left(\mathrm{mg} \mathrm{kg}^{-1}\right)$ & $0.510^{* *}$ & 0.011 & $0.497^{*}$ & 0.365 & 1 & & \\
\hline Soil OM (\%) & -0.311 & $0.528^{* *}$ & 0.358 & $0.415^{*}$ & 0.024 & 1 & \\
\hline Soil pH & 0.220 & $-0.635^{* *}$ & $-0.411^{*}$ & $-0.511^{* *}$ & -0.098 & $-0.806^{* *}$ & 1 \\
\hline
\end{tabular}

\section{Conclusion}

The challenge of maximizing crop productivity of vulnerable soil types (e.g. sandy soils) is to find out ecological intensification strategies for promoting their water and nutrients use efficiency with minimum inputs of synthetic compounds (e.g. mineral fertilizers and pesticides). Symbiotic $\mathrm{N}_{2}$ fixation using bacterial inoculation has attracted attention since a long time as an eco-friendly technique for crop intensification and intercropping plantation. In this research, Bradyrhizobium inoculant and humic substances fertigation was investigated as a modern technique for improving fertility and crop productivity of drip-irrigated sandy soils compared to compost and mineral application treatments. The scientific hypothesis of this research depends on the existence of flavonoid analogue in humic substances that can enhance expression of nod genes related to $\mathrm{N}$ fixation. Bradyrhizobium and humic substances fertigation improved water and nutrient supply potentials of soil and maximized growth and yield of peanut. This technique, can provide a long-term simultaneous localization of bioactive materials with high potentiality for ecological intensification of drip-irrigated sandy soils. However, attempts should be undertaken to improve the viability potential of this technique to compensate the extra cost and labor for procuring humic substances. Further field 
investigations should be undertaken with several leguminous field crops and symbiotic N-fixing bacterial to establish a holistic approach for widespread application.

\section{References}

Abd-Alla, M.H. 1994. Solubilization of rock phosphates by Rhizobium and Bradyrhizobium. Folia microbiologic,39:53-56.

Abd-Alla, M.H., S.A. Omar and S.A. Omar, 2001. Survival of rhizobia/bradyrhizobia and a rockphosphate-solubilizing fungus Aspergillus niger on various carriers from some agro-industrial wastes and their effects on nodulation and growth of faba bean and soybean. Journal of Plant Nutrition, 24:261-272.

Ahmad, N.,and M. Rahim, 2007. Evaluation of promising groundnut, Arachis hypogaea L. varieties for yield and other characters. Journal of Agriculture Research.45(3):185-189.

Alami, Y., W. Achouak, C. Marol,and T. Heulin, 2000. Rhizosphere soil aggregation and plant growth promotion of sunflowers by an exopolysaccharide-producing Rhizobiumsp. Strain isolated from sunflower roots. Applied and environmental microbiology,66:3393-3398.

Almeida, H.J., M.A. Pancelli, R.M. Prado, V.S. Cavalcante and F.J.R. Cruz, 2015. Effect of potassium on nutritional status and productivity of peanuts in succession with sugar cane. Journal of soil science and plant nutrition, 15:1-10.

Argaw, A., 2017. Organic and inorganic fertilizer application enhances the effect of Bradyrhizobium on nodulation and yield of peanut (Arachis hypogea L.) in nutrient depleted and sandy soils of Ethiopia.

International Journal of Recycling of Organic Waste in Agriculture.6:219-231.

Association of Official Analytical C., 1970. Official methods of analysis of the Association of Official Analytical Chemists: The Association.

Ayers, R.S., and D.W.Westcot, 1985. Water quality for agriculture: Food and Agriculture Organization of the United Nations Rome.

Canellas, L.P., F.L. Olivares, N.O. Aguiar, D.L. Jones, A. Nebbioso, P. Mazzei,and A. Piccolo, 2015. Humic and fulvic acids as biostimulants in horticulture. Scientia Horticulturae, 196:15-27.

Canellas, L.P., F.L. Olivares, A.L. Okorokova-Façanha, and A.R. Façanha. 2002. Humic acids isolated from earthworm compost enhance root elongation, lateral root emergence, and plasma membrane $\mathrm{H}^{+}$-ATPase activity in maize roots. Plant physiology, 130:1951-1957.

Chapman, H.D., P.F. Pratt, 1962. Methods of analysis for soils, plants and waters. Soil Science.93:68.

Das, T., B.K. Saikia, B.P. Baruah,and D. Das. 2015. Characterizations of humic acid isolated from coals of two Nagaland Coalfields of India in relation to their origin. Journal of the Geological Society of India, 86:468-474.

Delgado, A., A. Madrid, S. Kassem, L. Andreu,and M.D.C. Del Campillo, 2002. Phosphorus fertilizer recovery from calcareous soils amended with humic and fulvic acids. Plant and Soil, 245:277286.

Domínguez-Ferreras, A., S. Munoz, J. Olivares, M.J. Soto and J. Sanjuán, 2009. Role of potassium uptake systems in Sinorhizobium meliloti osmoadaptation and symbiotic performance. Journal of bacteriology, 191:2133-2143.

El-Banna, M.F., A. Mosa, B. Gao, X. Yin, Z. Ahmad and H. Wang, 2018. Sorption of lead ions onto oxidized bagasse-biochar mitigates $\mathrm{Pb}$-induced oxidative stress on hydroponically grown chicory: Experimental observations and mechanisms. Chemosphere, 208:887-898.

Emami Bistgani, Z., S. Ataollah Siadat, A. Bakhshandeh, A. Ghasemi Pirbalouti, M. Hashemi, F. Maggi, and M. Reza Morshedloo, 2018. Application of combined fertilizers improves biomass, essential oil yield, aroma profile, and antioxidant properties of Thymus daenensis Celak. Industrial Crops and Products, 121:434-440.

FAO. 2019. Food and Agriculture Organization of the United Nations, FAOSTAT, FAO Statistics Division 2017, November, 2019.

Gao, T.G., Y.Y. Xu, F. Jiang, B.Z. Li, J.S. Yang, E.T. Wang,and H.L. Yuan, 2015. Nodulation characterization and proteomic profiling of Bradyrhizobium liaoningense CCBAU05525 in response to water-soluble humic materials. Scientific reports, 5:10836. 
Geisseler, D.,and K.M. Scow, 2014. Long-term effects of mineral fertilizers on soil microorganisms A review. Soil Biology and Biochemistry, 75:54-63.

Głąb, T. 2014. Water retention and repellency of a sandy soil amended with municipal compost. Compost science \& utilization, 22:47-56.

Gomez, K.N., A.A. Gomez 1984. Statistical Procedures for Agricultural Research. John Wiley and Sons, New York, 2nd Ed., p 68.

Gopalakrishnan, S., A. Sathya, R. Vijayabharathi, R.K. Varshney, C.L.L. Gowda and L. Krishnamurthy. 2015. Plant growth promoting rhizobia: challenges and opportunities. 3 Biotech, 5:355-377.

Hager, A., 2003. Role of the plasma membrane $\mathrm{H}^{+}$-ATPase in auxin-induced elongation growth: historical and new aspects. Journal of plant research.116:483-505.

Hernandez, O.L., A. Calderín, R. Huelva, D. Martínez-Balmori, F. Guridi, N.O. Aguiar, F.L. Olivares,and L.P. Canellas, 2015. Humic substances from vermicompost enhance urban lettuce production. Agronomy for sustainable development, 35:225-232.

Hu, F., C. Zhao, F. Feng, Q. Chai, Y. Mu,and Y. Zhang, 2017. Improving N management through intercropping alleviates the inhibitory effect of mineral $\mathrm{N}$ on nodulation in pea. Plant and soil, 412:235-251.

Hui, L.I., W-t Feng, X-h He, Z.H.U. Ping, H-j Gao, S.U.N. Nan, and M-g Xu, 2017. Chemical fertilizers could be completely replaced by manure to maintain high maize yield and soil organic carbon (SOC) when SOC reaches a threshold in the Northeast China Plain. Journal of integrative agriculture, 16:937-946.

Hungria, M., L.H. Boddey, M.A. Santos,and M.A.T. Vargas, 1998. Nitrogen fixation capacity and nodule occupancy by Bradyrhizobium japonicum and B. elkanii strains. Biology and Fertility of Soils, 27:393-399.

Ingham, S.C., J.A. Losinski, M.P. Andrews, J.E. Breuer, J.R. Breuer, T.M. Wood, and T.H. Wright, 2004. Escherichia coli contamination of vegetables grown in soils fertilized with noncomposted bovine manure: garden-scale studies. Applied and environmental microbiology, 70:6420-6427.

Jackson, M.L, 2005. Soil chemical analysis: advanced course: UW-Madison Libraries Parallel Press.

Jannin, L., M. Arkoun, A. Ourry, P. Laîné, D. Goux, M. Garnica, M. Fuentes, S. San Francisco, R. Baigorri and F. Cruz, 2012. Microarray analysis of humic acid effects on Brassica napus growth: involvement of N, C and S metabolisms. Plant and soil, 359:297-319.

Kermah, M., A.C. Franke, S. Adjei-Nsiah, B.D.K. Ahiabor, R.C. Abaidoo, andK.E. Giller, 2018. $\mathrm{N}_{2}-$ fixation and $\mathrm{N}$ contribution by grain legumes under different soil fertility status and cropping systems in the Guinea savanna of northern Ghana. Agriculture, Ecosystems \& Environment, 261:201-210.

Khan, Z., H. Rho, A. Firrincieli, S.H. Hung, V. Luna, O. Masciarelli, S-H Kim,and S.L. Doty, 2016. Growth enhancement and drought tolerance of hybrid poplar upon inoculation with endophyte consortia. Current Plant Biology, 6:38-47.

Khorasaninejad, S., A. Àlizadeh Ahmadabadi,and K. Hemmati, 2018. The effect of humic acid on leaf morphophysiological and phytochemical properties of Echinacea purpurea L. under water deficit stress. Scientia Horticulturae, 15:314-323.

Kononova, Ma. M., 1961. Soil organic matter, its nature, its role in soil formation and in soil fertility. Soil organic matter, its nature, its role in soil formation and in soil fertility.

Lazali, M., M. Zaman-Allah, L. Amenc, G. Ounane, J. Abadie, and J.J.Drevon, 2013. A phytase gene is overexpressed in root nodules cortex of Phaseolus vulgaris-rhizobia symbiosis under phosphorus deficiency. Planta, 238:317-324.

Liu, Y., X. Jiang, D. Guan, W. Zhou, M. Ma, B. Zhao, F. Cao, L. Li,and J. Li, 2017. Transcriptional analysis of genes involved in competitive nodulation in Bradyrhizobium diazoefficiens at the presence of soybean root exudates. Scientific reports, 7:10946.

Lotfi, R., H.M. Kalaji, G.R. Valizadeh, E.K. Behrozyar, A. Hemati, P. Gharavi-Kochebagh,and A. Ghassemi, 2018. Effects of humic acid on photosynthetic efficiency of rapeseed plants growing under different watering conditions. Photosynthetica, 56:962-970.

Mäder, P., A. Fliessbach, D. Dubois, L. Gunst, P. Fried, andU. Niggli, 2002. Soil fertility and biodiversity in organic farming. Science, 296:1694-1697. 
Martínez, E., F. Domingo, A. Roselló, J. Serra, J. Boixadera,and J. Lloveras, 2017. The effects of dairy cattle manure and mineral $\mathrm{N}$ fertilizer on irrigated maize and soil $\mathrm{N}$ and organic $\mathrm{C}$. European Journal of Agronomy, 83:78-85.

Mosa, A., A. El-Ghamry, P. Trüby, M. Omar, B. Gao, A. Elnaggar,and Y. Li, 2016. Chemomechanical modification of cottonwood for $\mathrm{Pb}^{2+}$ removal from aqueous solutions: Sorption mechanisms and potential application as biofilter in drip-irrigation. Chemosphere, 161:1-9.

Mosa, A.A., 2012. Effect of the application of humic substances on yield, quality, and nutrient content of potato tubers in Egypt. In: Sustainable Potato Production: Global Case Studies. Springer. p. 471-492.

Muscolo, A., T. Papalia, G. Settineri, C. Mallamaci, and A. Jeske-Kaczanowska, 2018. Are raw materials or composting conditions and time that most influence the maturity and/or quality of composts? Comparison of obtained composts on soil properties. Journal of Cleaner Production. 195:93-101.

Nardi, S., P. Carletti, D. Pizzeghello, and A. Muscolo, 2009. Biological activities of humic substances. Biophysico-chemical processes involving natural nonliving organic matter in environmental systems, 2:309-335.

Noroozisharaf, A.,and M. Kaviani, 2018. Effect of soil application of humic acid on nutrients uptake, essential oil and chemical compositions of garden thyme (Thymus vulgaris L.) under greenhouse conditions. Physiology and Molecular Biology of Plants, 24:423-431.

Omirou, M., D.A. Fasoula, and I.M. Ioannides, 2016. Bradyrhizobium inoculation alters indigenous AMF community assemblages and interacts positively with AMF inoculum to improve cowpea performance. Applied Soil Ecology, 108:381-389.

Peters, J., S. Combs, B. Hoskins, J. Jarman, J. Kovar, M. Watson, A. Wolf,and N. Wolf. 2003. Recommended methods of manure analysis. University of Wisconsin Cooperative Extension Publishing: Madison, WI.

Sánchez, A., A. Artola, X. Font, T. Gea, R. Barrena, D. Gabriel, M.Á. Sánchez-Monedero, A. Roig, M.L. Cayuela, and C. Mondini, 2015. Greenhouse gas emissions from organic waste composting. Environmental Chemistry Letters, 13:223-238.

Saturno, D.F., P. Cerezini, P. Moreira da Silva, A.Bd. Oliveira, M.C.Nd. Oliveira, M. Hungria, and M.A. Nogueira, 2017. Mineral nitrogen impairs the biological nitrogen fixation in soybean of determinate and indeterminate growth types. Journal of Plant Nutrition.40:1690-1701.

Selim, E.M.,and A. Ali Mosa. 2012. Fertigation of humic substances improves yield and quality of broccoli and nutrient retention in a sandy soil. Journal of Plant Nutrition and Soil Science.175:273-281.

Selim, E.M., A.A. Mosa, and A.M. El-Ghamry, 2009. Evaluation of humic substances fertigation through surface and subsurface drip irrigation systems on potato grown under Egyptian sandy soil conditions. Agricultural Water Management, 96:1218-1222.

Sheldrick, B.H., 1984. Analytical methods manual 1984: Research Branch, Agriculture Canada Ottawa,, Canada.

Silva, L.R., M.J. Pereira, J. Azevedo, R. Mulas, E. Velazquez, F. González-Andrés, P. Valentão and P.B. Andrade, 2013. Inoculation with Bradyrhizobium japonicum enhances the organic and fatty acids content of soybean (Glycine $\max$ (L.) Merrill) seeds. Food Chemistry, 141:3636-3648.

Song, J., Q. He, X. Hu, W. Zhang, C. Wang, R. Chen, H. Wang,and A. Mosa, 2019. Highly efficient removal of $\mathrm{Cr}$ (VI) and $\mathrm{Cu}$ (II) by biochar derived from Artemisia argyi stem. Environmental Science and Pollution Research, 26:13221-13234.

Spaccini, R., V. Cozzolino, V. Di Meo, D. Savy, M. Drosos and A. Piccolo, 2019. Bioactivity of humic substances and water extracts from compost made by ligno-cellulose wastes from biorefinery. Science of The Total Environment, 646:792-800.

Spaink, H.P. 2000. Root nodulation and infection factors produced by rhizobial bacteria. Annual Reviews in Microbiology, 54:257-288.

Tilman, D., C. Balzer, J. Hill, and B.L. Befort, 2011. Global food demand and the sustainable intensification of agriculture. Proceedings of the National Academy of Sciences.108:2026020264. 
Uddin, M.B., M.A.S.A. Khan, S.A. Mukul, and M.K. Hossain, 2008. Effects of inorganic fertilizers on biological nitrogen fixation and seedling growth of some agroforestry trees in Bangladesh. Journal of Forestry Research,19:303-306.

Vincent, J.M., 1970. A manual for the practical study of the root-nodule bacteria. A manual for the practical study of the root-nodule bacteria.

Walkley, A.,and I.A. Black, 1934. An examination of the Degtjareff method for determining soil organic matter, and a proposed modification of the chromic acid titration method. Soil science, 37:29-38.

Xin, X., S. Qin, J. Zhang, A. Zhu, W. Yang,and X. Zhang, 2017. Yield, phosphorus use efficiency and balance response to substituting long-term chemical fertilizer use with organic manure in a wheat-maize system. Field Crops Research. 208:27-33.

Zanin, L., N. Tomasi, A. Zamboni, D. Sega, Z. Varanini,and R. Pinton, 2018. Water-extractable humic substances speed up transcriptional response of maize roots to nitrate. Environmental and Experimental Botany, 147:167-178.

Zhang, W., H. Wang, X. Hu, H. Feng, W. Xiong, W. Guo, J. Zhou, A. Mosa, and Y. Peng. 2019. Multicavity triethylenetetramine-chitosan/alginate composite beads for enhanced $\mathrm{Cr}$ (VI) removal. Journal of Cleaner Production, 231:733-745.

Zhao, C.X., L.H. Jia, Y.F. Wang, M.L. Wang, and Jr. ME. McGiffen, 2015. Effects of different soil texture on peanut growth and development. Communications in Soil Science and Plant Analysis, 46:2249-2257.

Zhu-Barker, X., S.K. Bailey, M. Burger and W.R. Horwath, 2017. Greenhouse gas emissions from green waste composting windrow. Waste management.59:70-79. 